\title{
CIF/IFC Gold Medal Winners Gagnants de la médaille d'or de l'institut
}

Étienne Bachand,

Cégep de Baie-Comeau

Originaire du Centre du Québec, Étienne Bachand est venu sur la Côte-Nord pour y découvrir les atouts d'une région forestière. Doté d'une personnalité franche et d'une grande facilité d'adaptation, il a su naturellement s'associer aux causes forestières.

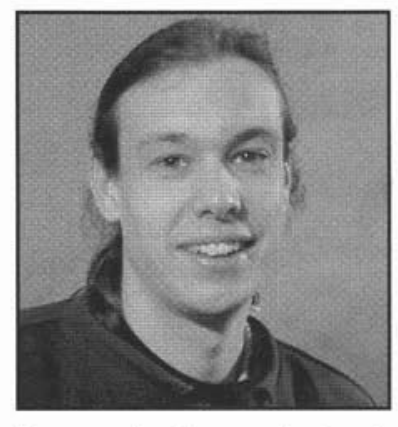
Étienne a participé dès la première année de ses études à l'après-verglas dans sa région d'origine. En effet, il a su transférer les techniques acquises dans l'évaluation de cette perturbation majeure. Apprécié de ses maîtres de stage et de ses professeurs, il a servi d'exemple discret à ses jeunes collègues. Calme et organisé, Étienne Bachand sera sûrement un technicien forestier apprécié et efficace.

\section{Geneviève Brière, Université Laval}

Madame Geneviève Brière, étudiante au baccalauréat coopératif en Génie du bois à la Faculté de foresterie et de géomatique de l'Université Laval, a été, tout au long de ses études universitaires, très impliquée dans la

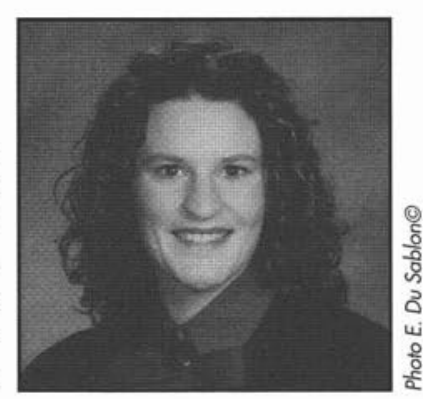
vie socio-culturelle de la Fac-

ulté. Pendant trois ans, elle a fait partie, principalement à titre de trésorière, du comité exécutif de l'Association des étudiants et étudiantes en foresterie de l'Université Laval.

De plus, madame Brière s'est impliquée dans de nombreuses activités sportives tant comme organisatrice que participante. Parallèllement à ses nombreuses activités parascolaires, elle a su maintenir un excellent dossier académique en plus d'effectuer quelques séjours à l'étranger. En plus du français, sa langue maternelle, elle possède une certaine maîtrise de l'anglais et de l'espagnol et elle a déjà accumulé une experience diversifiée sur le plan international.

Peggy Brimsacle, Cégep de la Gaspésie et des Iles

Originally from a little village North of Bathurst, New Brunswick, Peggy started her life in Forestry at the Cegep de la Gaspésie et des Iles in 1997. Leaving behind her native province with her three children, Peggy was looking for a profession she could excel at as well one that would provide financial stability.

Three years since that day she left home to attend Cegep, Peggy has completed the Forest Technology Program with the distinction of being our Gold Medal winner. Previously, she was awarded the «Chapeau les Filles» prize for women studying in nontraditional programs. She is, therefore, leaving us after meriting many honors and also considering the fact that, during her last semester, she chose to follow all of her courses in French. She has also been very involved in student activities. Her greatest accomplishment has been co-ordinating the fundraising campaign for her class visit to British Columbia in April, before graduation. She has also found time to be a great mother for her three girls.

The Professors of Forest Management are very proud of this young lady's achievements. She has shown us all that, with a little determination and perserverance, everything is possible. We wish her the best of luck, which she so deserves.

Tera Blake, College of New Caledonia

Tera Blake was this years recipient of the CIF/IFC Gold Medal award for the College of New Caledonia. Tera is a graduate of the Forest Resource Technology class of 2000.

Tera is from the Williams Lake area of central British Columbia. She comes from a forestry family where both her mother and

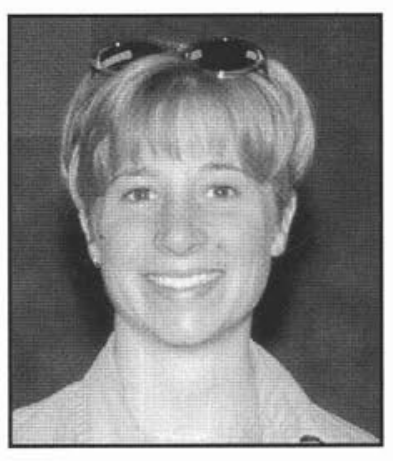
father have worked in some aspect of forestry. Tera did not choose forestry as a career path early on but came to realize the potential that exists in the forests for skilled practitioners. She chose $\mathrm{CNC}$ as the school to study at and worked hard to win a seat in the program.

The recommendation for this award was made based on many of Tera's academic and personal characteristics. In addition to maintaining a strong academic performance she work tirelessly on behalf of the schools forestry club. She was recognized for academics in 1999 by being placed on the president's list. She served on the forestry clubs executive and was instrumental in organizing class activities, fund raising and maintaining a positive class spirit. Her hard work on behalf of her fellow students and on behalf of the forestry program was exceptional.

Tera is planning to continue her forestry studies as she pursues a degree in forestry. Her present goal is to become a member of the Association of B.C. Professional Foresters. Clearly she is off to a good start and will continue to contribute positively to her forestry community.

\section{James Daigneault, SIAST}

James joined the Integrated Resource Management program through the SIAST partnership with Dumont Technical Institute in La Ronge. James has demonstrated a keen interest in a broad range of resource management issues and practices including forestry. His consistent academic performance has 
demonstrated a good work ethic and his work reflects a personal pride and attention to quality. James has also been an active participant in a variety of intramural sports and activities. James has also been a good spokesperson for his class and program during and we wish him well in his future resource career. James is presently employed with Saskatchewan Environment and Resource Management in his home community of Ile A La Crosse.

\section{Simon Deschênes,} Cégep de Sainte-Foy

Natif de Beaumont, près de Québec, Simon complète actuellement son diplôme en aménagement forestier. Faisant preuve d'initiative et de débrouillardise, Simon est un bon vivant dont les capacités d'apprentissage et d'adaptation sont remarquables. Sa franchise et son honnêteté sont des qualités appréciées de tous.

À l'automne 99, Simon a effectué un stage pratique sur le territoire de la compagnie Donohue sur la Côte-Nord où il a pu assister des contremaitres sur la coupe et la construction de chemins. Auparavant, à l'été 99, il a travaillé comme débroussailleur pour une entreprise privée en Abitibi. De plus, il travaille à temps partiel plusieurs années sur la ferme familiale.

Ses principaux loisirs sont l'équitation, la motoneige et la mécanique automobile.

La médaille d'or de l'Institut forestier du Canada lui est remise, accompagnée d'une bourse de 250 \$, gracieuseté de la compagnie Denharco inc. de Saint-Hyacinthe.

\section{Janette Desharnais, Université de Moncton}

Madame Janette Desharnais, originaire de St-Pierre-Jolys au Manitoba, s'est vue accordée la médaille d'or de l'Institut forestier du Canada pour l'école de sciences forestières de l'Université de Moncton. Cette distinction est attribuée annuellement à un étudiant ou une étudiante qui s'est illustré durant ses études de baccalauréat en sciences forestières par l'excellence de son dossier

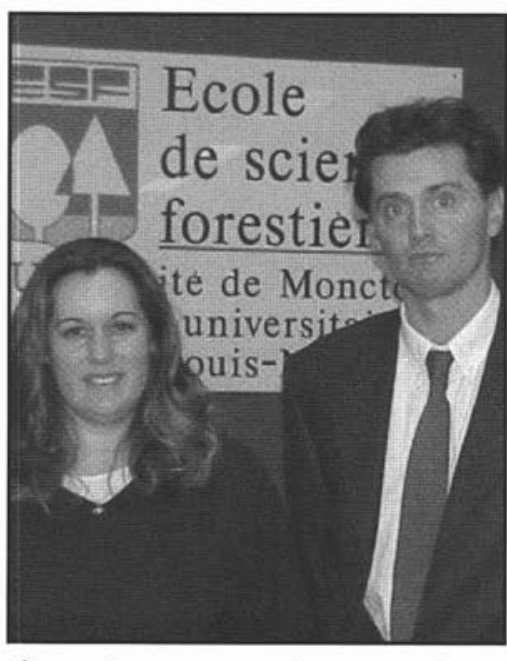

À gauche: Janette Desharnais; à droite: Richard Barry, chef du secteur sciences forestières de l'ÉSF, Université de Moncton. académique, ainsi que par ses qualités personnelles. Madame Desharnais a maintenu un rendement académique élevé tout a long de sa formation, tout en étant impliquée dans la vie étudiante et dans les activités de la communauté universitaire. Avant de débuter ses études à l'ÉSF, Mme Desharnais avait obtenu un Baccalauréat en microbiologie et biochimie de l'Université du Manitoba où elle a développé ses intérêts pour les sciences biologiques et ses aptitudes à traiter les problèmes complexes par l'approche scientifique. Elle a d'ailleurs démontré tout au long de ses études une rigueur élevée dans ses travaux scolaires, une grande intégrité intellectuelle, et un solide sens critique, des qualités qui en font une étudiante remarquable. Toutes nos félicitations à Janette Desharnais et tous nos souhaits de succès dans ta carrière.

\section{Édith Doucet, Cégep de St-Félicien}

Suite à l'annonce de Monsieur Marcel St-Gelais, superviseur de la voie de sortie foresterie, je désire poser ma candidature comme récipiendaire de votre prix. Le but de cette lettre est de vois expliquer les motivations qui me poussent à m'inscrire, les raisons pour lesquelles je me crois admissible.

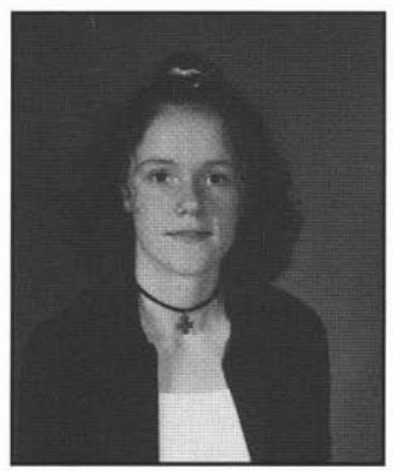

Tout d'abord, je tiens à souligner les résultats scolaires exemplaires que j'ai toujours su obtenir. Bien sûr, pour parvenir à ces résultats, j'ai dû faire preuve d'une grande persévérance afin que mes notes demeurent ce qu'elles sont. Mon ambition personnelle m'a aussi beaucoup aidé, car je cherche constamment à me surpasser. Je crois tout de même que les efforts que j'ai dû déployer en valent le coup, car je suis fière de mon accomplissement personnel. Toutefois, ma vie n'est pas seulement axée sur les études. Je fais beaucoup de bénévolat, entre autres pour Opérations Nez Rouge et la Croix Rouge. De plus, je développe mon talent artistique en travaillant à des dessins, en découvrant le monde de la calligraphie et en la pratiquant. J'ai d'ailleurs mis mon talent au profit du groupe de foresterie en réalisant un dessin abstrait, celui-ci a été imprimé sur des chandails que l'on vend pour financer un voyage d'étude pour le groupe.

Maintenant que je suis pratiquement parvenue à l'échéance de mes études collégiales, desquelles je tire une grande fierté, je désire entrer sur le marché du travail pour pouvoir mettre en pratique les notions de foresterie que j'ai acquises. J'ai déjà une l'occasion de les mettre en application l'été passé en travaillant pour une coopérative de la région, mais ce n'était qu'un emploi d'étudiant. Je désire maintenant avoir un poste de technicien forestier me permettant de fair de la foresterie. Je suis fière d'être rendue là où j'en suis car il n'est pas toujours facile pour une femme de se faire respecter et apprécier dans ce domaine.

Je vous assure donc du grand intérêt que je porte à la science forestière, des efforts que je suis prête à déployer pour m'impliquer de tout mon être pour la pratiquer. J'espère que la persévérance dont je fais preuve ne passera pas inaperçus et que ma candidature retienne votre attention.

Je vous prie d'agréer mes salutations les meilleurs. 
Jennifer Erlendson,

University of British Columbia

Jennifer Erlendson is this year's winner of the CIF Gold Medal for all round outstanding best student in the Faculty of Forestry at UBC. She will be receiving her B.S.F. in Forest Resources Management at the Convocation ceremony in June.

For each of her four years in the forestry program, Jennifer has

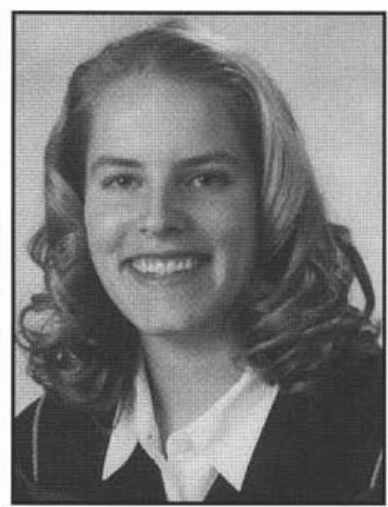
been an honours student. In her fourth year she received both the Kapoor Singh Siddoo Scholarship in Forestry and the Oscar Soderman Memorial Scholarship.

Jennifer was involved with the graduation committee to organize and fundraise for the graduation banquet that took place in March. Her non-academic interests include soccer, futsal, hockey and co-rec basketball.

Starting in May, Jennifer will be working in Mackenzie for Slocan Forest Products as an assistant silviculture forester.

\section{Cinthia J. Forsey,}

Northern Alberta Institute

of Technology

Cinthia J. Forsey is this year's recipient of the CIF Gold Medal award in the NAIT Forest Technology program. She maintained academic honours standing in both years of the program. In her first year she served as Treasurer of the Forest Technology Student

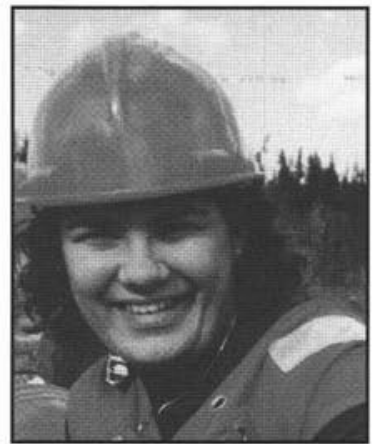
Association and in her second year she served as the Student Association President. She was involved in the planning of most study functions, including Bull-of-the-Woods and the graduation ceremonies. She has also been active in her church. One of her interests is teaching school children about sustainable forestry. By maintaining many contacts in forestry she tries to establish lasting friendships. In the summer of 1999 Cindy was on a fire job with Alberta Land and Forest Services in the Northwest Boreal Region. She is currently employed with Canfor in Grande Prairie.

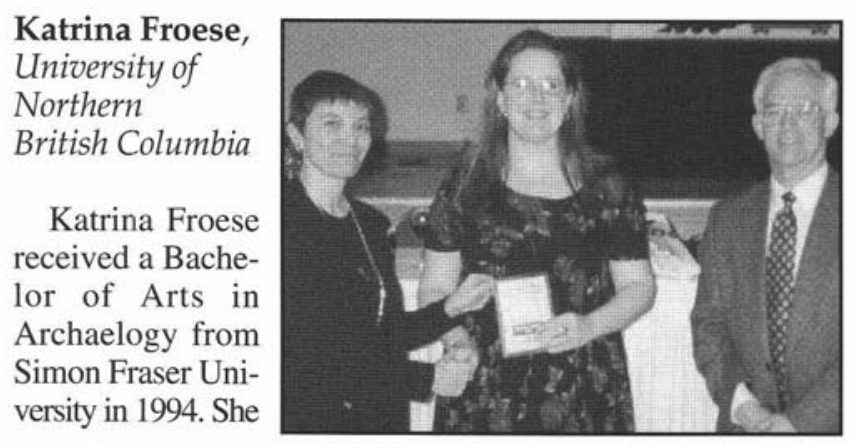

pursued these interests by participating in archaeological excavations in Tel Beth, Israel; Youra, Greece; Quesnel Forks, B.C.; and Barkerville, B.C. She has held several forestryrelated jobs since beginning the BSc in Natural Resources Management, Major in Forestry, at UNBC. These include fieldwork, lab work, and database development for the Ministry of Forests Prince George Region; communications and data management for the Northern Land Use Institute (UNBC); and, web design and database management for the Northern Forest Research and Extension Partnership. Katrina is an outstanding student, having maintained a Grade Point Average above 4.0 during her studies at UNBC. Her academic accomplishments have earned several scholarships, including the Marumi Lumber Company Scholarship (1998 and 1999), Weldwood Scholarship (1998 and 1999), H.R. Macmillan Scholarship in Forestry (1997), and William John Splan Scholarship in Forestry (1997). Katrina is regarded as a leader among her classmates and peers, who cheered loudly when Katrina was announced as the CIF Gold Medal recipient for this year's graduating class.

Sid Jules, Nicola Valley Institute of Technology

In April of 2000 Sid Jules Graduated with his second Diploma of Technology in Natural Resource Management. He was in the top of his graduating class. Sid has exemplified good citizenship through the years at NVIT. In his four years at NVIT Sid completed one year of College Preparation (top student for his year) and both the Forestry and Fish/Wildlife/Grassland/Recreation options of the Natural Resource Technology Diploma Program. Combining his technical expertise with his strong interpersonal communication and leadership skills, Sid will be well equipped to serve his community.

\section{Charlotte Léger, Cégep de Rimouski}

Après avoir obtenu avec distinction un baccalauréat en communication de l'Université Concordia, je me suis dirigée en technique d'aménagement forestier au Cégep de Rimouski dans le but d'unir ces deux domaines. Cette union me permettra d'agir comme

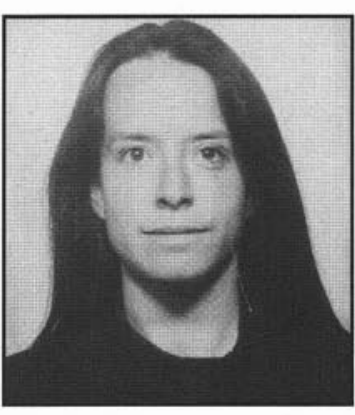
intermédiaire entre le public, le gouvernement, les industries et les différentes associations. Il est important que chaque partie soit sensibilisé et au fait des diverses méthodes d'interventions mises en application en forêt.

De plus, grâce à mes connaissances forestières, je pourrai participer à l'élaboration de meilleurs outils de gestion maximisant ainsi le rendement obtenu de la matière ligneuse tout en respectant la développement durable et la biodiversité du milieu.

Un stage forestier en France et un stage au sein d'une firme de consultation forestière de la région de Montréal m'ont permis d'acquérir une expérience pertinente. 


\section{Audrey Murray, Cégep de Chicoutimi}

Audrey Murray est une étudiante originaire de Laterrière, une importante muncipalité industrielle, agricole et forestière située en banlieue de Chicoutimi. Audrey complète actuellement son collège III et devrait accéder au marché du travail, dès la fin de mai prochain.

Notre comité des bourses l'a choisie à partir d'une sélection préliminaire de 10 élèves de collège III, qui répondaient positivement à l'ensemble des critères proposés par votre organisation. Audrey s'est démarquée de ses confrères et consoeurs en nomination par la qualité de son dossier académique.

Audrey possède, non seulement un dossier académique éloquent, mais aussi elle fait preuve de bonnes attitudes et habiletés lors des ateliers en forêt. Elle possède une bonne personnalité qui lui permet de s'adapter, voir même de faire face à des situations très difficiles. Son esprit d'initiative, son leadership et sa rapidité d'éxécution des tâches furent souvent cités en exemple par ses professeurs. Elle doit sa bonne forme physique à son entraînement régulier en «work-out». Enfin son implication dans les activités étudiantes n'est pas négligeable. En effet, elle s'est impliquée dans l'organisation d'activités d'intégration scolaire, d'information professionnelle et du bal des finissants de la promotion hiver-2000, en assurant la mise en page et la rédaction de l'album des finissants.

Audrey est une étudiante intelligent, efficace et s'intègre très bien à des équipesde travail. Bref, elle possède plusieurs des qualités recherchées par un employeur sérieux.

\section{Georges Viel ing.f. Président du comité des bourses}

\section{Joseph Oldford, Maritime Forest Ranger School}

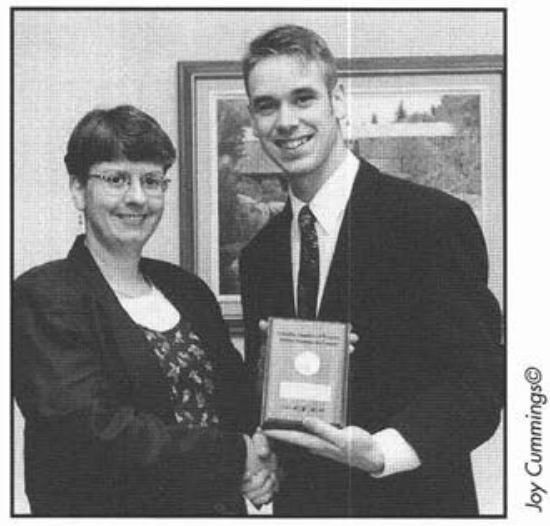

Joe came to the school as a single student (21 years of age) with previous training in Electrical Engineering from the University College of Cape Breton, Nova Scotia. Joe also had extensive previous training in the Canadian Armed Forces Reserves. He continued to demonstrate very high standards in both field and academic aspects of his studies and is a very hard working, dedicated and determined person. Joe was a great help to many of his colleagues and served his class very well as Vice President on the Student Council, and on several student committees. He is an excellent forest technician currently serving the forestry community of New Brunswick in the employ of the Carleton Victoria Wood Producers Association in Florenceville. We are proud to present him to you.
David Pelster, University of Alberta

David entered the University of Alberta Forest Management Program 3 years ago. By that time he already had obtained a diploma and a degree in Biological Sciences. Since then he has done exemplary work, both in individual and group-based studies. His extra-curricular activities included working as a teaching assistant in the Department of Renewable Resources, volunteering at the University of

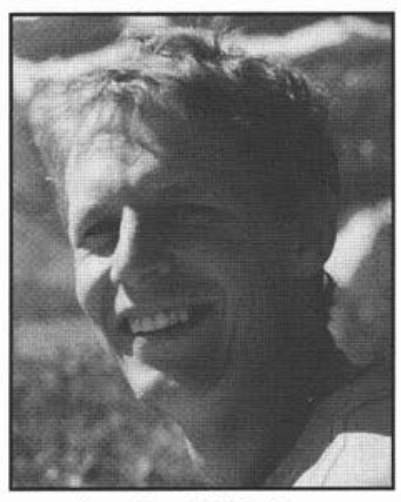
Alberta International Center, volunteering for CJSR (the campus radio station), and playing on the intramural hockey team. He spent the last two summers working for Millar Western Forest Products in Whitecourt Alberta, and is now employed by Silvacom Ltd., a forest consulting company based out of Edmonton.

Jason Plaskett,

Sault College of Applied

Arts and Technology

Jason Plaskett is an honours graduate of the Forestry Technician CO-OP program at Sault College of Applied Arts and Technology in Sault Ste Marie, Ontario. He has achieved high academic standings throughout his scholastic career and has obtained numerous certifications including,

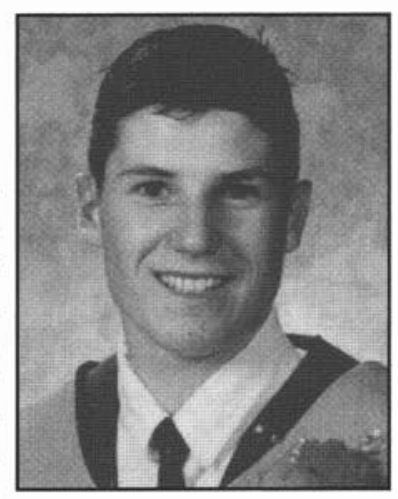
S-100 Forest Fire Fighting, CPR/First Aid, Tree Marking Certification, and a valid pesticide spray license.

In high school Jason excelled as an athlete while he maintained the academic distinction of an Ontario scholar. Prior to attending college, Jason participated in an international exchange program (Canada World Youth) between Canada and Cuba. Living on a native reserve in northern Saskatchewan, he experienced the many intricacy's of native culture and taught physical education during an employment placement within the community. After the Canadian phase of the program, Jason was immersed into the Cuban lifestyle and strived to learn the Spanish language.

Jason has also studied abroad at the Evo Institut of Forestry in Finland. He completed assignments in various regions of Finland as well as in neighbouring countries. Through his plights volunteering at the "Porotutkimusaema" (Reindeer Research Centre) in northern Lapland to hunting wild bore in Estonia, Jason has strengthened his character and broadened his educational experiences.

From a seasonal fishing guide at fly-in Pine Portage Lodge in northern Ontario to presently roughnecking on the service rigs in the oil patch of Alberta, this young man strives to develop and keep an open mind. A special thank you to the Canadian Institute of Forestry for recognizing such an outgoing indi- 
vidual and worthy recipient of this Gold Medal Award for the 1999 academic year.

\section{Valérie St-Amour, \\ Cégep de \\ l'Abitibi-Témiscamingue}

Valérie St-Amour ressent une attirance particulière pour le milieu naturel depuis sa plus tendre enfance. Mère d'une fillette de quatre ans et étudiante à temps plein au Campus de Rouyn-Noranda, Valérie s'est dirigée en Technologie forestière après un bref passage en Sciences humaines. Femme de terrain et consciente de la valeur de la forêt, elle entend apporter sa contribution profes-

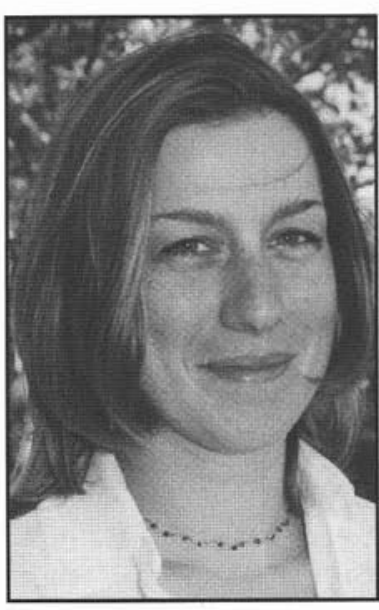
sionnelle dans une utilisation intelligente de la ressource forestière. Sa sensibilisation pour la santé et la sécurité au travail en foresterie la pousse, après son Diplôme d'études collégiales, vers dans ce domaine.

Adam Stark, British Columbia Institute of Technology

Based on an examination of the performance of students in the second year of the Renewable Resources Forestry program, in individual forestry courses as well as overall grade-point average, attitutude, and personality, we have selected Adam Stark as the recipient for this year.

Adam is a second year Forestry student who is currently enrolled in the fourth of four terms required for a diploma in Forestry. Adam has the highest GPA of any student currently in the second year of the Forestry program. Following a year that included numerous course marks over $90 \%$, last term, Adam received marks in the nineties in both the Technical Communications course and the Forest Insects and Diseases course.

Adam is a congenial member of the second year class and gets along exceptionally well with fellow students. He can be relied upon to be a conscientious member of any lab group with which he engages and approaches project group work with energy, enthusiasm, and depth.

We thank you for the opportunity to select Adam Stark for the year 2000 Gold Medal Award.

\section{Deborah Stuart, Selkirk College}

Deborah Stuart completed her two diploma in Forestry Technology in April 2000. During her time at Selkirk College, Deborah achieved a cumulative grade point average of 3.92 . Deborah was also involved in various student activities including intramural sports and Renewable Resource club events. Deborah has taken a job with Resource West Consulting in Kelowna for the coming field season. Selkirk College wishes Deborah well in her endeavors and congratulates her on her academic achievements.
Peter Wright, Yukon College

Peter Wright is the first recipient of the Canadian Institute of Forestry, Klondike Section Gold Medal for Scholastic Achievement. The Gold Medal is the highest award presented by the Canadian Institute of Forestry for academic performance and leadership. The award is presented to the top student in forestry or renewable resource programs at Canadian Universities and Colleges.

Peter moved to the Yukon in 1996 from BC where he worked a variety of forestry-related jobs, including forestry operations, scaling milling and horse logging. Peter is also an avid skier, snowboarder, mountain biker and golfer. Before coming to the Yukon he obtained a diploma from the Ski Resort Operation and Management Program from Selkirk College and worked at resorts in Japan and BC.

Peter is well deserving of the CIF Gold Medal. Not only did he excel in the Yukon College Renewable Resource program where he graduated with honors from the program in 1999, he is also active in many community programs. Peter currently works as a paramedic and volunteers as an RCMP auxiliary and a fireman with the Whitehorse Fire Department. Peter serves on the board of directors for CPR Yukon and is a member of the Young Rider to promote safe snowboarding. Peter is still waiting for an opportunity to break into a Renewable Resource field in the Yukon.

Please help me in congratulating Peter Wright, the first winner of the CIF Klondike Section Gold Medal Award.

Pascal Pagé, La Cité collegiale

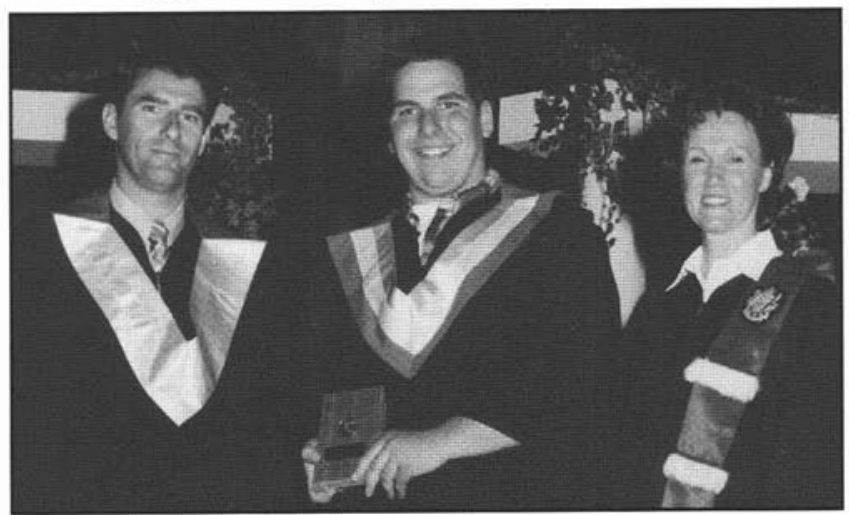

Other Gold Medal Winners

Shawn Goodyear

College of the North Atlantic

Jodi Maepea

Lakehead University

William Bablitz

Malaspina University-College

Jennifer Hughes

Sir Sandford Flemming College

Ellen Dalton

University of New Brunswick 